鶏の飼料としての油脂の諸問题

勝木 辰男

(日本獣医畜産大学)

\title{
Problems on Lipids Used in Poultry Diet
}

Tatsuo KatsukI

(Nippon Veterinary and Zootechnical College)

飼料の分野で過去 10 年の間にめざましい発展をとげ たもののひとつに，油脂 (lipid)，特に動物脂肪を家畜・ 家离の飼料として使用することが急速に増加したことが 挙げられる.これまでは，これらの脂肪の大部分は，石 鉿の製造に使用されてきた。ところが、技術開発が進 み，合成洗绪が他の原料をるとにして㱔造されるように なつたので，これまで動物脂肪によつて作られていた洗 刘の代りに，合成洗剂が备方面にわたつて活用されるよ うになつた，その結果，食用に適しない動物脂肪が， フ メリカなどでは飼料として大量に用いられるようになつ t.

油脂添加による高エネルギー飼料のはじまつたのは, JoHNSON ${ }^{49}$ の説明にもあるように，1950 年頃であるが，

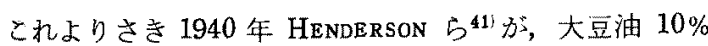
添加は，無添加にくらぺて，ひなの8週後の生長によい 影響があることを報じたのが，飼料としての油脂につい ての研究発表の初めの頃のものである.

油脂を飼料に添加することはどのような理由からか, また，どのような利点があるかという点について， ENGMINGER ${ }^{29}$ は次のような事項を举げている.

1. エネルギー源として．2. 脂溶性ビタミンの担体と して. 3. 飼料の風昧をよくする．4. 必須の不飽和脂肪

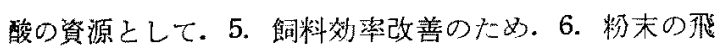
散定除々. 7. 飼料混合機の磨損の隇少. 8. 飼料の外 観・触感がよくなる９．ペレットにするこるが容易に なる。

1 のエネルギー源として考元られるといらことは，実 㻮の飼料で実験した報皆がある。た之充ば NABER ら 淿実油粕 (TDN 63) が大豆粕 (TDN 78) の半量之 代替する場合，脂肪を $2 \%$ 添加すれば育噍に刘する䗁料 効率は同じになるという報告.あるいは，セルローズの 配合量が $18 \%$ ななそれ以下の場合に扔いては，脂肪
を添加して，基礎飼料とほぼ等しい代謝エネルギーとす れば，增体量は明らかな差異がなくなるという BEGIN の報告. ふ亦ま（TDN 64）に脂肪を添加してトウモ口 コシ（TDN 82）と代替与ると增体結果がよい上いう

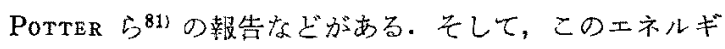
一も従来加謵好られているように，油脂怔蛋白質や澱 粉質の 2 倍以上のエネルギー発登生する。

2 の脂溶吽ビタミンの担体として役立つということ は，従来も認如ら机ていたことであり，3の飼料の風味 をよくすることも事実である。

4 の必須の不館和の脂肪酸の資源として油脂添加が有 効であるという点に関しては，すでに BURR ${ }^{81}$ はリノー ル酸, リノレイン酸它, さらに TURPEINEN ${ }^{1099}$ はフラキ トン酸が必須の脂肪酸として証明しているので当然なこ とであり，最近同エネルギー值の油脂袁まない飼料と 油脂を含えだ飼料で，後者がよりすぐれた生長を示した が，これは油脂添加により必須の脂肪酸を与えられたこ とも，矢の理由の一つと考无られると EDWARDS ら 報告している。

5 の飼料勃染改善については，COMBS ${ }^{111}$ の総説にもあ るように，1952年にはひな党 $3 \mathrm{lb}$. の体重にするのに 10 週間かかり，11b. の增体に要する飼料の量は $2.81 \mathrm{lb}$. 必要としたが，油脂を多く深加することに上り，1958 年 には同じくひな老 $3 \mathrm{lb}$. の体重にするのに 7 週間で， $1 \mathrm{lb}$. の増体に要与る飼料の量は $1.04 \mathrm{lb}$. と少くなつた。

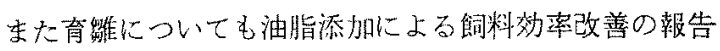
结 SUNDE ${ }^{1001}$ はじめ多数の報告があり，座卵化ついても

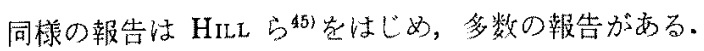

6，7，8，9，のことについては，いられももつとあな ことて，泟脂家飼料に添加する有利点として十分考光ら れる。

このように飼料に油脂索添加することに多くの利点が 
两るが，このほかに油脂添加の利点はないか，また油脂 添加についても多くの問題点があるので，以下それらの 点について述でてみたい.

\section{各種油脂の飼料価値}

動物性油脂は柔かいものをグリース（grease），硬い ものをタロー(tallow) といつている. CULLEN ら"14 各種のグリース，タローのひなによる代謝エネルギーと 見加けの吸収率定報しててる。（次の括弧内の数值は前 者忐代㖣エネルギー，単位 Cal./lb., 後者は見かけの吸 収率，単位\%)。 上質白色グリース (3.925，95)，黄色 グリース $(4.326,93)$, 褐色グリース $(3.830,84)$, 家 离ダリース $(4.630,94)$, 上質タロー $(3.597,85)$, タ ロー No. 2 (3.451, 87), ビーフタロー (3.451, 79). この結果から，ひなに﨎してタローはグリースより効果 が劣るが，これはグリースの融点が $40^{\circ} \mathrm{C}$ 以下，すなる ちひなの体温に近いということにも関係しているである うが，次のような条件にも左右される，BIELY ら蜼 料中の蛋白質含量が高くなるにともない利用率が向上す ると報じている，すなわ方，蛋白質含量が $22 \%$ の場合 のタローの利用菜注 $80 \%$ であるが，蛋白質舍量が $33 \%$ の場合はタローの利用率は $87 \%$ に向上している.また タローの利用率は鶏の年令とともに增大し，ひなでは利 用率が 4 週令で $70 \%$ ，成鵎では $81 \%$ と向上することを RENNER ら ${ }^{88}$ は報してている。また, FEDDE ら ${ }^{341}$ は牛の胆 汁范わずか添加守ることによりタローの消化率が向上す ることや，カルシャム含量が高いとタローの吸収がわる くなるという報告をしている。

動物性油脂の魚油は，筀気中で酸化されない上うにし た場合に $1.4 \%$ 以下添加なら洨効果がある31.

植物性油脂のなた称油とひまわり油の代謝エネルギー はタローにほぼ等しく292，上らむろこし油と大豆油のひ な生長促進効果, 飼料効率はラードと同様でありた ${ }^{17}$.

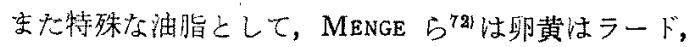
大豆油，とうも学こし油と同様な生長促進効果をあらわ すとし，この原因は䖝白質ではなく，卵黄油の中にUGF が含まれているのではないかと考えている，そしてむし UGF が原因であるならば， ラード，大豆油，とうもる こし油などにも普過的に含まれていると考光ている。こ

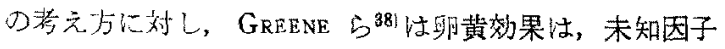
効果というよりは，秀しろ既知の柴整素のバランスがよ 加たた好であるといら見解学登している。

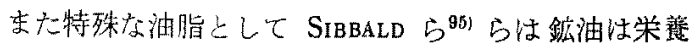
源としてび利用されないものと考光られると報じ，
また，加水分解加ら脂肪酸を蒸溜するとき残る黑色の 粘性の物質，スチル・ボトム（still botom）と名付社ら れている物質むひなの生長に影響がないと報じてい合。

以上各種の油脂の解料洒值を述べたが，この洒值怡 PePPER ら ${ }^{801}$ が述べているように短期間の飼養試験元 つては知ることができない：また，消化率測定の場合に も，MEHRING $5^{71)}$ が報じているように，尿中の脂肪安 無視すると，脂肪の消化率は $6 \%$ 以上の誤差がでること などのことも考虑に入れて価值を判断しなければならな いと考点る。

\section{油脂添加と他の栄養素との関係}

飼料に油脂を添加して，高エネルギー飼料をつくつた 場合, 油脂を添加した効果をあらわすためには, 他の栄 養素とのバランスが問題となる.この点に関し、るつと も多くの報告のあるのは蛋白質との関係である。ひなの 生長あるいは飼料奻率に関しては，飼料中のエネルギー 合量を高めるにとるない，蛋白質含量をあげなければな らない，すなわ方，飼料中のエネルギー含量と蛋白質含 量のバランスを適当に保ななければならないという報告

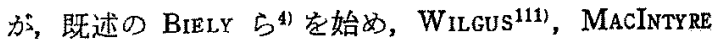
$5^{60)}$, Donaldson $5^{23)}$, Mraz $5^{74)}$, Leong $5^{53)}$, DougLAS ら ${ }^{25)}$ の報告など多くある.また産卵鵎について も，産卵率をあげるため，あるいは飼料炏率を高めるた めには, 油脂添加と同時に, カロリー・蛋白比 (calorieprotein ratio）が適当した数值になるように蛋白質含量 を考虑しなければならないという，HILL ら柆始め MCDANIEl $5^{68,691}$, Hochreich $5^{47)}$, Thornton $5^{1061}$ ど多くの報告がある. KUMMERowS ら ${ }^{51)}$, REISER $ら^{86)}$, DONALDSON $5^{221}$, MARCH $5^{61,62)}$, LEONG $ら^{\text {63) }}$ 法油脂添 加することにより，ひなのコリン・リボフラビン・葉酸 およびメチオニンの所要量它増大すると報じ，勝木ら ${ }^{501}$ は油脂添加飼料ではコリン・メチオニン・ビタミンE添 加がひなの生長ならびに飼料要求率改善に必要であると

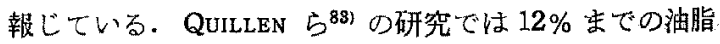
它含む飼料では，コリンは $900 \mathrm{mg} / \mathrm{lb}$. まで高劣こと により，メチオ二ン要求量を節䄪する。これは両者成メ チル基給源になるためであると説明しなおコリンの最 適量柱铝料の油脂とメチオニン含量によつて变り，油脂 含量汃 $3 \%$ を超元る部分の $1 \%$ について $20 \mathrm{mg} / \mathrm{lb}$. 追加

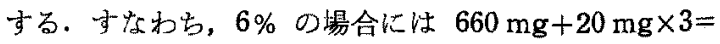
$720 \mathrm{mg}$ がコリンの飼料 1 ポンド中の添加量であるとし ている。

SUMMERS ら ${ }^{99)}$ は有効リン含量が不足の飼料に油脂を 
添加粠るとひなの体の灰分含量が明らかに低下した

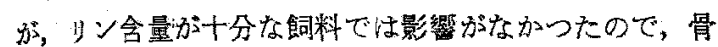
の形成に対して，飼料中の油脂とリン含量の間には明ら 加な関係があることを認めている。

EDWARDS ち ${ }^{26)}$ は飼料中の蛋白質と熱量含量多同じで も，油脂を多く配合したすのほどカルシウム要求量が高 まり，また，脂肪の種類と品質によつて，カルシウムの 要求量が暴なることを明らかにした。すなわち，低カル シウム飼料に油脂を添加した場合の生長促進勃果は, ヨ ード価 134 の大豆油が最もよく,ついでラード, 水素添加 したシード価 94 の大豆油, ビーフタロー (beef tallow) およびョード価 57 の水壳添加した大豆油の順であつた と報じている.

\section{脂肪添加と環境}

いずれの栄養素の効果についても，その結果を論ずる 場合には，铇のおかれている環境がどのような状態であ るかということ知らなければ，環境によつてそれぞれ の栄養素の奻果に差違が出ることは当然である。油脂に ついてもそのような環境との関係を検討しなければ 落らないと思うが，この問題に関しての報告が少い。 DONALDSON ${ }^{24)}$ の研究はその一つであるが結諭にまではい 㹸つていないすなおち，対照飼料に $10 \%$ の油脂を添 加すると、いずれのバタリーに打いてもひなの生長が明 らか改善されたが，その割合注新しいバタリーを用い た場合が大きくなつた．対照飼料では新旧バタリーいず れの場合も同じであつた. この成績から, 腸内の微生物 がひなの油脂の利用婆に影響することが予想されるが， 今後さらに詳細に研究する必要があると報している。

\section{育雛飼料としての油脂}

育雛鸰料としての油脂を考察方る場合, 生長の改善, 飼料勃率の改善,およびひなはどの程度油脂に对して耐 性があるか，その活かに前述したことと重複する事項と しては添加する油脂の種類，あるいは他の栄食素との関 孫などが挙げられる. 生長の改善については, 役立つと する研究者と，生長率は变らないとする研究者があり， 蚼料数率の改善には役立つという意見に多くの研究者が 一致している。すなおち，SIEDELER 5 ${ }^{961}$, SuNDE ${ }^{1021}$ ， RUNNEL $9^{903}$ ，DONALDSON $5^{211}$ 飼料効率の改善には有 勃であるが，生長率は恋らないといい，その反対に， Roberston 5 $5^{891}$, Kummerow ${ }^{51)}$, Carver $5^{9}$, Pepper

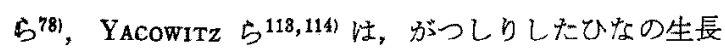

の改善には，飼料に油脂を添加することの必要を認めて いる.

また MARION ら $5^{67)}$ は雌びなの生長初期には油脂添加 が明らかに糼果があるが，産卵前ころには勃果はなくな つてしまうと報じている。

SUNDE ${ }^{1011}$ は，オレイン酸, リノレン酸, およびリノー ル酸は生長率に影響がなかつたが，飼料効率の改善に役 立つた. 一方，水素添加した油脂およびステフリン酸を 添加しても飼料勃率の改善はみられなかつた。ひなは長 連鎖状の飽和脂肪酸を利用できないことが判つたと報じ ている.

このような報告から, 油脂添加の時期, あるいは添加 した油脂を構成している脂肪酸の種類の相違によつて効 果にも差が見われるということが考えられる.

次にひなの油脂に対する耐性性相当強く，RAND $5^{85}$ の報告によれば，トウモロコシ怞 $30.7 \%$ 添加，すなわち 全熱量の $57 \%$ ，非蛋白態熱量の $97 \%$ の場合に増体量な らびに蛋白質蓄積は一番よかつた。また，DONALDSON ${ }^{241}$ の報告でも、アミノ酸，ミネラル，ビタミンが十分であ れば, 飼料の油脂含量を $33.8 \%$ にしても生長の低下性 認められないといっている. ただし, 油脂の添加量の増 加によつて，油脂の消化率は減少し，安た炭水化物の消 化率の低下も認められたと BOLTON ら”は報告している。 従つて，ひなは油脂に対する而姓は相当強いが，その油 脂の消化率あるいは，他の栄莀素の消化率はわるくなる ので, 添加量については最大奻果発揮する量につい て，龵れぞれの油脂について研究の余地があるら.

\section{ブロイラー飼料としての; ;脂}

ブロイラー飼料としての油脂を考察する場合，生長彸 果とか，飼料要求率などにおよほす影響など，既述の問 題点を除けば，性別に対する勃果の問題，飼料の形態の 問題，脚の色調，仕上つた肉の色調，あるいは風味の閭 題, さらに蓄䅡脂肪の脂肪酸組成の問題，窒菜の蓄積の 問題などが挙げられよう。

まず，性別に対する油脂添加の影留では，THOMAS

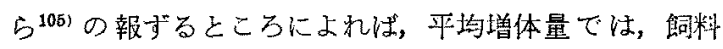
効率が高くとも低くとも，雄ブロイラーが䧳ブロイラー よりよかつた。そして，体脂肪は飼料効率のいかんにか かわらず雃プロイラーのほうが雄プロイラー上りも多く ついたまた，性が同じブロイラーでは，飼料㚳率のす くれているものが, 悪いものにくらべて明らが体脂肪 含量が低く，この傾向は雄プロイラーよりは倠ブロイラ 一に括いて著しいといら結果を示した。 
飼料索ペレット (pellet form) にすれば油脂添加の有 無にかかわらずマッシュ（mash）の場合よりは生長や 飼料効塐が改善されるが，油脂添加の場合のペレット化 は，油脂無添加の場合汪ど効果はなかつたと PEPPER ら

プロイシーの場合屠体の脚の色調も考えなければなら ない，黄色では美味に感ずるし，鉛色では死真を感ず

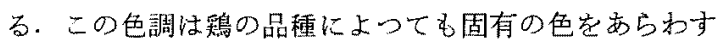
が，油脂の添加の場合，添加油脂の種類により脚の色調 が堂つてくる. CARVER ${ }^{10)}$ は色調の標準を5段階に別け，

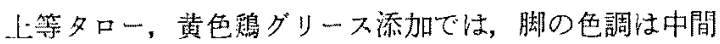
のバター黄色に仕上り，同じグリースでも黄色動物グリ 一スでは4段階目の明黄色に仕上ると報じている。また 同氏は各種の油脂あるいは製法の相違によつて足指のキ サントフィール含量を測定し，油㸝の種類により，また 同種類の油脂の場合でも製法の相違によつて，ブロイラ 一の脚の色調が遈うことを明らかにしている：しかし， この色調の相違をあらわ可子については明らかにして いない。同様のことは, BIRD ${ }^{5)}$ HAMMOND $5^{391}$, HEIMAN ら苂なども報告している。

ブロイラーの肉の色調についても，むまり色のあせた もの恓值が少らのでこの色調についても相当考慮し なければならない問題であるが，WILLIAMs ${ }^{112 ! ~}$ の報告に 上れば $20 \%$ の動物性脂肪，大豆油，トウモ口コシ油, 棉実油を添加したものでは，ブロイラーの肉の色調はわ るくなるこ上が楒められ，この原因についてはいかれて いないか，ブロイラー出荷 2.5〜3 週前にキサントフィ 一ル含含物䆩を与えれば，この色調のわるくなること ガ防げるとしている。

肉の風崃の問題は，わ机われ日本人に岋区別しにくい 圤もあるが，欧米人にとつては多大の関心のある問題 て，乙の点油脂添加上ブロイラー肉の風味の関俰ととり あげた発表がある。たとえば安定化した白色グリース老

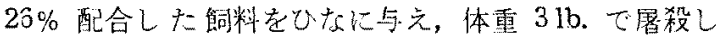
て，その風昧を比校したところ，油脂添加の有無にかか

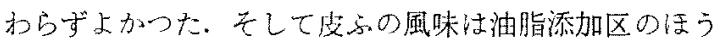
がよかたとLEONGら ら21 報じている。さらにARSCOTT ら 心れた量が多加つたか， $6 \%$ 多ローを添加したるのては

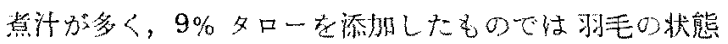

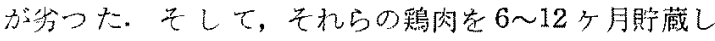
こも風味は变らなかつたと報じている。しかしなが方

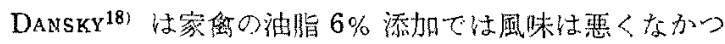

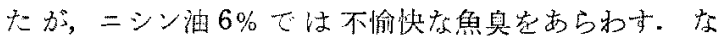
寺, ニシン油を減じて, ニシン油 $3 \%$ 上動物性油脂 $3 \%$
添加でも不愉快な魚奥があり，さらにニシン油定減じて

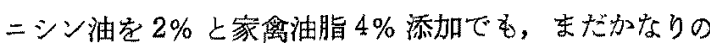

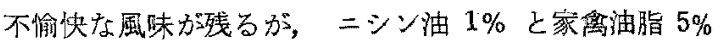
添加で，ようやく風昧がわるくない鵎肉ができたと報じ ている.

これらの報告から，添加する油脂の種類によつて，ま る種類では上例のように $26 \%$ も添加してを風昧を害さ ないぶ，ある锺類ではかずか $2 \%$ の添加でもか放り風味 をわるくすることに䦛係がある。

添加する油脂安構成する脂肪酸の相違によつた，鴙体 脂肪の構成脂肪酸の差違があることが当然考えら光。 深加する油脂の構成期肪酸住次の例の上うに大きな差造

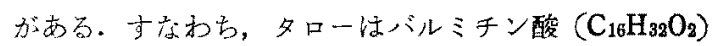
$25 \%$, ステアリン酸 $\left(\mathrm{C}_{18} \mathrm{H}_{36} \mathrm{O}_{2}\right) 21 \%$, オレイン酸 $\left(\mathrm{C}_{18} \mathrm{H}_{34} \mathrm{O}_{6}\right) 36 \%$ が主成分であり，ラードはパルミチン 酸 $25 \%$ ，ステアリン酸 $12 \%$ ，オレイン酸 $44 \%$, リノレ イン酸 $\left(\mathrm{C}_{18} \mathrm{H}_{30} \mathrm{O}_{2}\right) 12 \%$ が主成分であり，大豆油はバル ミチン酸 $19 \%$,オレイン酸 $18 \%$,リノレイン酸 $51 \%$ 加主 成分である。また，水素添加したヤシ油ははとえど大部 分が飽和脂肪酸であって，もつとる多いのはラウリン酸 $\left(\mathrm{C}_{12} \mathrm{H}_{22} \mathrm{O}_{6}\right)$ て $52 \%$ ，つきにミリスチン酸 $\left(\mathrm{C}_{14} \mathrm{H}_{26} \mathrm{O}_{2}\right)$ が約 $20 \%$ ，そのほかハルミチン酸，ステアリン酸，カブ リン酸 $\left(\mathrm{C}_{10} \mathrm{H}_{20} \mathrm{O}_{2}\right)$ 加それぞれ $8 \sim 10 \%$ である.同じ 植物油でもサフラワー油は不飽和脂肪酸が大部分で, もつをも多いのは2重結合を2個有するリノール酸 $\left(\mathrm{C}_{18} \mathrm{H}_{32} \mathrm{O}_{2}\right)$ て $72 \%$ ，飽和脂肪酸のパルミチン酸が $14 \%$, 2 重結合 1 誠定有するオレイン酸が $12 \%$ であ。 MACHLIN $5^{58)}$ は水素添加のヤシ油を給与した鵴の腹部 の脂肪，肝臓，および心臟の脂肪は，サフラワ一油在給 与したものにくらべて，ラウリン酸およびミリスチン酸 が明らかに多くなり，通にりノール酸は明らかに隇少し

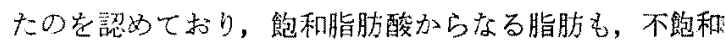
脂肪酸からなる脂肪も体脂肪の組成飞影響する。

また，田先ら ${ }^{104)}$ は発育中の空素バランスを测定した。 結果, 油脂添加の增与につれて, 琹素の蓄積が多加つた こと定報じている。

\section{産卵鵎飼料としての油脂}

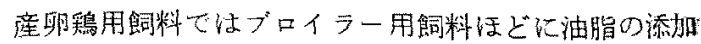
量は多くない、油脂添加の第1義である工ネルギーとい う点について，産卵鵎はひなよりる工ネルギーは少くて

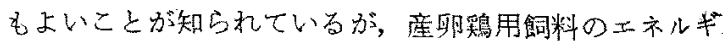
一算出基礎は，むなの試䮖結果に基づいているので，こ

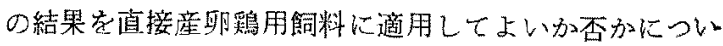




\section{て明らかでない。}

産卵鵴用飼料として油脂を考えるとき，油脂を添加し た嚗合，鷄の体重にどの上うな影響があるか，産卵率に 对しては, 飼料要求率に対しては, あるいは油脂を添加 した飼料を損取した鵴の生産した卵の重さ，受精率，ふ 化率，そして蔇にはどのような影饗があるか，木た， 産卵堅の場合にどのくらいまで油脂添加に耐えるかとい う問題が検討の諸問題となるう。

油脂添加は，体重に対して影響がないという報告が多 い. MARCH ら ${ }^{64,65)}$ は油脂添加飼料を特にヶージ飼養の 産卵鷄に給与すると, 従来は必要以上に体重が増加する と考えられていたが，同氏らの実験では，渾 1 年令， 2 年令，および 3 年令の産卵䳂，あるいは別の油脂添加 32

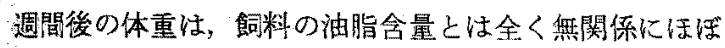
一定に維持されたと報じている.

出た，平飼いの場合にも，HILL (6) 注油脂添加は産卵 殦の体重において, 油脂無添加已差違が少く，過度の脂 肪の蓄積は観察されなかつたとしている。なお，同氏は 蓄皘する脂肪の程度は, 飼料中の土ネルギーの水準だけ でなく、さしろェネルギーと蛋白質との均衡に大いに関 媇する・すべての栄養素との均衡を保たせることは，油 脂添加によつて高熱量水隼の飼料を，もつとも効果を発 揮させるために必要なことであることを強調している。

まゔ, 産卵率に対する油脂の影響の報告としては, 最 初は低瀻維の高络ルギ一飼料として取扱われた。すな わち QUISENBERRY ら ${ }^{84)}$ 户 SKINNER ら ${ }^{98)}$ は高エネルギー 飼料（低瀻維合量）型铝料を用いると，産卵率が向上す ること老明らかにしている。つで LILLE $ら^{551}$ は産卵 用飼料にシード添加すると産卵率において目立つた增

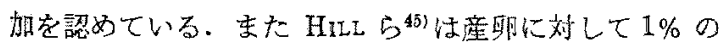
油脂添加は産卵率が増加することを報告している。

これらの報告法油脂添加は産卵率にはよい影響它与光 るという報告であるが，次には添加時期などにより影䀺 がある場合と，影響のない場合を報じた報告がある。

MARION $5^{67)}$ は産卵の初期には飼料中に脂肪酸を含む必 要のあることを報じているが，影響がなかったという報

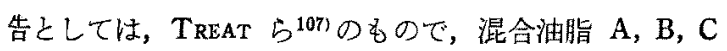
の3種類，あるいは動物性泏脂をとれ它れ $2.5 \%$ または

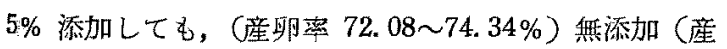
卵率 73.51\%) のものとくらべて産卵率に影響肪なかつ たこと定諗めている。さらに，次には㯊影響のあつた場 合として，実驗的に特殊の精製饲料，士なわ台抗酸化剂 含量务低く、リノレイン酸含量の高い飼料で泣産卵率は

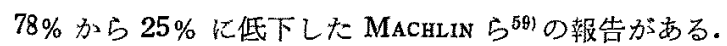

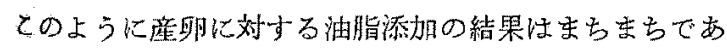

るが，最後の特殊飼料の場合を除いて，結果に相堂があ るのは，上記 2〜3 の報告にもあるように，産卵中のい ずれの期間に好影響があるが，またはないか、亦るいは 油脂以外の他の栄養素之の均衡の問題, さらに対照飼料 の内容など，劣る前提条件のもとにおける油脂の影響と いうこと考えなりればならないものであるう。

飼料要求率についてを，最初のころは飼料中の繊維含 量の高低によるエネルギーの高低と関係つけて産卵に対 する飼料要求率が論ぜられていたが，高エネルギー飼料 の有効を認め, その後油脂添加之飼料要求率に進えでき

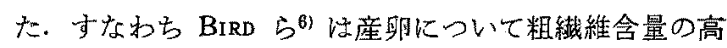
低と逆に，生産効率が上いとと発表しており，SINGSEN $\zeta^{977}, G_{E R R Y}{ }^{37}$ ) は高エネルギー飼料（低織維合量）洼低 エネルギー飼料 (高織維含量) より1ダースの即生産に 要する飼料は少くてすむと報告している.さらに H HLL $ら^{48,44)}$, PrICE ら ${ }^{82)}$ も同様 1 ダースの卵生産についての 飼料の所要量は飼料のエネルギー含量の增加によつて隇 少したことを報告している。また，TREAT ら ${ }^{107)}$ は 1 ダ ースに要する飼料は $2.5 \%$ または $5 \%$ 油脂添加で 3.17 6. 09\% 減少したと報し，MCDANIELら ${ }^{68)}$ はケージ飼養 の産卵鷄に $17 \%$ 粗蛋白質含量の飼料安生産エネルギー $88 \mathrm{Cal} . / \mathrm{lb}$. 高めると，飼料効染は $12.2 \%$ 堌加すること

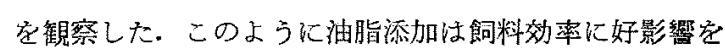
与えることは，ほほ一致した見解で，これは飼料中のエ ネルギーが高をれば，蛋白質から熱量に迴ることが少く てすむなどのことから，卵の単位生産量当りの飼料の所 要量が減少してくるためであるう。

次に畉重については， СомBs ら ${ }^{18)}$ 㤌 $9 \%$ の加水分解 した動物性および植物性油脂，㐫るい将 $10 \%$ タロー学 添加する之産町率，卵質に性影響がないが，卵重が明ら が增加したことを報じ，MARION ら ${ }^{66)}$ は $10 \%$ のトウ モロコシ油を添加したところ，対照にくらべ $6.1 \sim 8.2 \mathrm{~g}$. 增加したことを認め，SHUTzE ら $5^{941}$ はトウモロコシ油添 加飼料恃無添加飼料にくらべて明らか纪卵重が増加した こと認めている。こ机法最大卵重を得るための未知因 子が、トウモロコシなどのようにリノール酸含量の多い 植物性油脂に多く含ま机ているためではないかとしてい る.としてタロー深加はトウモロコシ油添加と無添加の 中閐の卿重を示したが，統計的には有意ではなかつた。 油脂を添加主ることにより，卵重が增大主ることには㴽 湆見が一致しているようであるが，その原因がただ単 に飼料中のエネルギー索高めるためだけか，あるいは卵 重增大に対する未知因子があるかという点については不 明である。

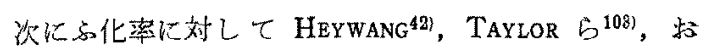


よび REISER R $^{877}$ は低脂肪飼料に加えた油脂仿ふ化率に意 義ある影響はないと報告している.一方，MrLLER ら は実用飼料，半精製ラード添加鲖料，まよび半精製無脂

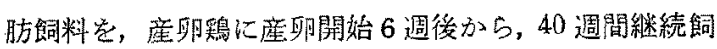
蕉した結果，受精率については 3 飼料の間に大差はなが つたが，40週間の終期には無脂肪飼料給与区では，心化 に要する時間が 24〜36 時問長くなつたと報告している. すなわち，正常のふ化に油脂の必要であることを認めて いる.また，MARION ら66! も゙ルコース扎び精製大豆 虫白質を主体とする脂肪久之の精製飼料と，これに $10 \%$ のトウそロコシ油を配合した飼料を与えて実験したとこ わ，前者の飼料妾与えた平均ら化率仙 $21.7 \%$ で低から たが，後者の飼料莸与光た平均占化率法 $58.9 \%$ と高く なつたとして，化におよぼす油脂の効果它認めている。

油脂の卵質におよほ寺影響については，まづ卵殻につ いて HunT 5 48) 性，産耶鵎用飼料に配合したダーが カルシウムの利用にどのように影響するかを，卵毅の形 成についで調べた結柴，卵殻の离質はタローを飼料に 12\% まで配合しても，明らかな影響がなかった。また 卵㲄の品質はカルシウム含量の低い飼料を与えると悪く なつたが，この場合タローを添加しても，それ以上に悪 い影響はなかつたと報じている。

卵白・卵黄の亲色について Evans ら ${ }^{301}$ は次のような。 ことを報じている． $2.5 \%$ の粗製の棉害油を含さ飼料を 給与した産卵鴊の卵を 6 ケ月冷蔵庫に䝪蔵すると, 卵白 が淡紅色となり，卵黄は䱦肉色の部分が広がつた。また， 棉実粕定 10\% たは 15\%配合した場合，卵白は淡紅色 のものが認められた・粗製棉実油を真空蒸溜したものを 与えると，淡紅色の卵白がなくなるので，卵白を淡紅色 化する因子は技らく熱不安定なものであるう。また EVANS $5^{311}$ は棉実油・ごを油・サフラワー油・桐油・落 花生油・米ぬか油・市まに油・大豆油・圧搾とうむろこ し油・浸出とうもるこし油の 10 種頪を各々 $2.5 \%$ 添加

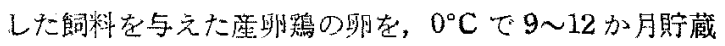
して，卵白・卵黄の変色を調へたとこる，異常は棉実油 給与区のみで,その区の卵白は蓇いピンク色上なり,卵黄

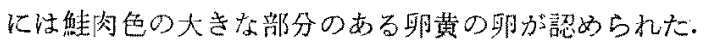
また, Masson $5^{701}$, Suenstone $5^{931}$, Doberenz $5^{191}$ は, スタータリヤ・フォーティダ油（Sterculia fortida oil，フオギり料约属する Java olive の木の実索粉㻊し， 溶媒で抽出したもの)，变たはスタークリン酸 (Sterculic acid $\left.\mathrm{CH}_{3}\left(\mathrm{CH}_{2}\right)_{7}, \stackrel{\mathrm{CH}_{2}}{=} \mathrm{C}\left(\mathrm{CH}_{2}\right)_{r} \cdot \mathrm{COOH}\right)$ 含む諆料党

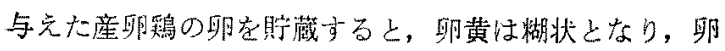
白性紅色となること空報告している。そこで DOBERENZ

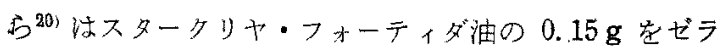

チンのカプセルに入れて投与して，䁌の物理的変化老請 ごた結果，ふつ5の卵の卵黄の $\mathrm{pH}$ は 6 であるが，この

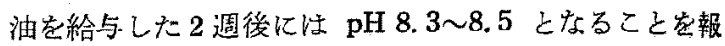
でている.

次に卵中の脂肪の組成は，飼料中の脂肪によつて影響 を受けやすい. FISCHER ら ${ }^{86)}$ は大豆油，サフラワー油を

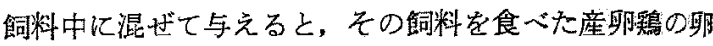
中にはリノレン酸のみが多くはつて和り，あまに油の場 合に法，卵中にりノール酸，リノレイン酸ともに多くな

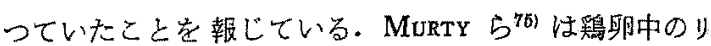
ノール酸，リノレイン酸の含量は，それぞれの脂肪酸の 飼料中の含量が高まるにつれて堌加するが，飼料中の含 量が $5 \%$ 以上になると一定值となる。そして，これらの 脂肪酸と同㭙に牛脂を添加すると，これらの脂肪酸の咀 卵中への移行量性減少する。これは牛脂の稀积効果であ るとしている. OSTRANDER ら ${ }^{77}$ 梳 10\%のとうもるこし 油を添加するとヨウ素化が堌加する。すなるらら卵黄の油 の不飽和の程度の堌加を認め，10\%牛脂添加によつて とうるるこし油の場合とは逆伅，対照飼料以下にヨウ素 価が低下したと報している。さらら Evans ら ${ }^{331}$ は棉実 油，スタークリフ・フォーティダ種実老与充た結果，䳜 即中に含まれる脂肪酸に共通していることは，ステフリ ン酸が増加し，オレイン酸が減少することである.しか し，飼料中の脂肪酸分布在比較すると，各飼料間に大差 は認められず，ステフリン酸，オレイン酸，リノレイン 酸の含量はそれぞれ，3，27，45\% 程度であつた。これ

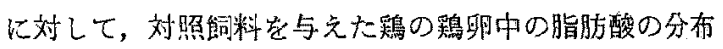
のうち, ステアリン酸, オレイン酸, リ/レイン酸の含 量は $10 ， 38 ， 18 \%$ 程度である. この結果から, 鴊卵に 蓄積される前にリノレイン酸が鵴の体内で水素添加され るか，鵎卵中の脂肪は大部分炭水化物加占成され，老 の際ステフリン酸が多量に合成されるかのいずれかと考 㒸られる。これ注棉实油や，スタータリフ・フォーティ ダ種宾の給与によつて, 血液や肝䜿のステアリン酸が増 加し、オレイン酸が減少することから、䀝肪酸の代㛛方阻 害されるむのと考光られる.この場合, 蓄䅡脂肪の脂肪 酸組成は，血液の脂肪酸組成之飼料の脂肪酸の中間であ り，飼料によく似ている。したがつて，この成績から，蓄 積脂肪の大部分は肝臟でその組成が变成される前に，蓄 積されれたものと考兊られるとしている。また，MACHLIN ら581 は大部分飽和脂肪酸少らなる水装添加のやし油と， 大部分が不飽和の脂肪酸からなる水素添加のサフラワー 油を産卵鶂に与鴌て卵中の脂肪酸を調べたところ，やし 油を給与した鵎の卵は，サフラワー油を給与したものに くらベて, ラウリン酸, ミリスチン酸,ミリストレン酸 
むよびオレイン酸含量がかなり多くなり，逆にリノール 酸およびアラキドン酸の含量は明らかに低下した．この ことから，飽和の脂肪酸からなる脂肪は，不飽和脂肪酸

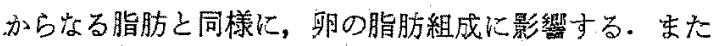
成鷄は必須の脂肪酸の久之に対し敏感ではない：これは 舶肪の組成に多量のリノール酸が合京れ，またアラキド 酸の減少する割合が低いためであるとしている。

卵黄のコレステリン含量は，用いた脂肪の種類によつ ては明らかな差異を認めなかつたと DAGHR ら ${ }^{15)} か ゙$ 報じ ている.

スポンヂ卯 (卵黄凝固)はマレイシヤ尿の草の実 (Malvacae)や熱処理してゴシポールを非活性化してい 店い棉実粕崖産卵舀に与えると起る。この原因につい て，原因となる有害脂肪酸を分離し，次の名前と構造を

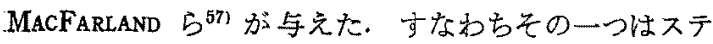
ロキューリック酸 (Steroculic acid) $\mathrm{CH}_{8}-\left(\mathrm{CH}_{2}\right)_{7}-$ $\mathrm{C}=\mathrm{C}-\left(\mathrm{CH}_{2}\right)_{7}-\mathrm{COOH}$ ，他の一つはマルバーリック酸

$\mathrm{CH}_{2}$

(Malvalic acid) $\mathrm{CH}_{3}-\left(\mathrm{CH}_{2}\right)_{x}-\mathrm{C}=\mathrm{C}-\left(\mathrm{CH}_{2}\right)_{y}-\mathrm{COOH}$

ただし $x+y=13$ となる.

\section{$\mathrm{CH}_{2}$}

産卵鵴に刘して脂肪をどの程度まで給与しても害がな いかという点については，油脂を与えたために特殊の病 気になる量というよりも，元来の目的が産卵を增進させ るかどうか問題にすることでるるから，産卵比対して 効果のなくなる量について述べたい８％字での脂肪添 加は，産卵率は堌大するが，それ以上では鷹卵率の向上

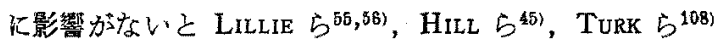
加報じている。 また WEISS ら 添加すると産卵が減ずることを報じている。

\section{脂肪と繁殖・性成熟}

MACHLIN 占 ${ }^{591}$ は不飽和脂肪酸のリノレイン酸を多量 飞与えた場合に，8週間で産卵率は78\%から $25 \%$ に低 下し受精率は $37 \%$ ，ふ化率は $0 \%$ となる。こ机にビタ ミンEを添加すると有効であると報じている.

宗た、スタータリヤ・フォーティダ油を給与するととさ 办，卵巣および輸卵管の発育が痋机ることを SCHNEIDER $ら^{911}$ が認め，EVANS ら ${ }^{321}$ は産卵鵴に棉実油またはスター クリヤ・フォーティダの種实を給与すると，その沺はス テフリン酸の割合活高くなるが、オレイン酸の割合が低

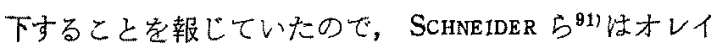
酸を多給したところ，スタークリヤ・フォーティダ油 搿与起因する性成熟の遅延なよび産卵菜の低下をある 程度軽減できると報じている。

\section{油脂添加と疾病}

飼料中に不飽和脂肪酸が多いと，ひなの脳鿒化症の原 因となり、ビタミンモや抗酸化剤の要求量が高くなるこ とが知られている。

油脂添加によって多く発生するようになつた疾病は脂 肪肝であろう。この症状はフメリカでは1954 年の終り 頃からみられるよらになり，その発生率は1956年にな つて急に增加している. 占ようどこの頃油脂を 6〜7\% 程度含む有名商標の飼料が急に市場に出迴り始めたの で,恐らくこれらの趼料のエネルギー含量吕高いことが，

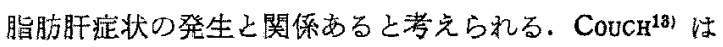
鵎が産卵索続けている間は, 整死之か, 脂肪肝症状の発 生などの問題はほとんどなかつたが，産卵が止ると，急 に過剩の脂肪を沈着して整死方るようになる。そてで，

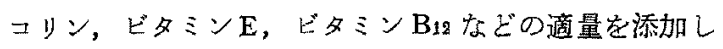
て予防すること，あるい蛋白質含量を高めてやること が効果があると説明している。

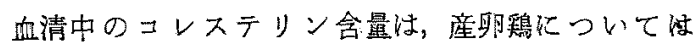
DAGHIR ら ${ }^{151}$ は，12\% の大豆油を配合したものは，対照 飼料給与区より低下し，12\% の白色グリースを添加し たものでは対照区にくらべて明らかに增加しなかったと 報じている。 また，EDWARDS ら ${ }^{281}$ は成鶏にトウモロコ シ油，ビーフ・タローラードを給与したが，血清コレ ステリン合量に明らかな差異は認められなかつたと報じ ている.ひなについては DAGHIR ら ${ }^{16)}$ は，8\%の動物性 脂肪を給与した区か，油脂無添加区あるいは植物性油脂 の大豆油給与区に比して明らかに高くなつた。また血清 コレステリン含量はいずれの詿駼区においても雄びなが 雌びなに比して明らかに高くなつたと報じている。

KEINHOLZ らウイスコンシン大学の研究者ら ${ }^{36)}$ は油脂 添加飼料を給与すると，場合によつては尻つつきあるい

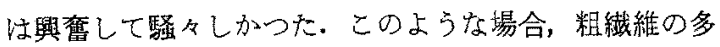
い跼料を配合すると尻つつきを防ぐことができたが，油 脂定添加して高エネルギーにした効果がなくなつてしま うとしている.

その任か，疾病ではないが，10\% 委たは $14.5 \%$ の油 脂を給与したひなでは，2.5\%の油脂を給与したひなに 比し甲状腺がささかつた。ただし甲状腺は小さくとも， 甲状腺ホルモンのサイロキシン (thyroxine) の分泌量 は必ずしも減少しなからたを MARCH ら ${ }^{631}$ は報じている。

また疾病予防染と油脂の適合性汇関して,コクシジウ 厶症の予防治療薬のナイカーバジン (nicarbazin) 含 省飼料にタローを添加した場合には，平飼い，バタリー 飼いと舟に生長が減退与るが，メチルエステルを添加し 
た場合には，両様式飼いちともに生長が增加したので， ナイカルバシンはタローよりメチルエステルによく適合

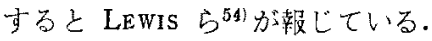

\section{油脂添加と抗酸化剂}

油脂を飼料に添加する場合に注意を要する点の一つ に，添加した油脂が酸化しないようにすることである う、添加した油脂が酸化す机は，遊離の脂肪酸ができた り，生産物に悪臭をつけたり，ビタミン類を破壊するた めである。これ定防止するために抗酸化剂を用いること が考えられる。

飼料に用いられる抗酸化剂上しては，次のような条件 に合わなくてはならない，1，毒性が少なく，抗酸化力 济強いこ上．2．溶解度が高く，安定な物質で西るこ之。 3. 味も臭気もなく，色もないこと．4．佂格が適当であ ることなどである。

これらの条件に合つた飼料の抗酸化削として BHA (butylated-hydroxy-anisole), BHT(butylated-hydroxytoluene), クェン酸 (citric acid), プロピールガレート (propylgallate) 杰た最近ではトリハイドロオキシン・ ブチロ・フェイン（trihydroxy-butyro-phenone）方用 いられよい結果が得られている.

\section{お゙わりに}

この総説においては，近年の報告を中心として，鶏の 飼料としての油脂について研究進展の概略を述べた。一 部はほぼ意見の一致をみているが，結果がまちまちの部

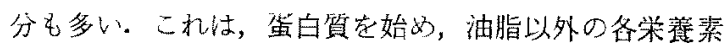
と油脂とのバランスの調整の破究が終局に隼していない ことや，をれに加光て環境の要因を加えた研究が末挥決 であるなど，油脂添加の効果离珢大に発揮ずために， 今後一畨の研究によつて解決されなけ扎ばならない点が 多いた放である.

\section{文献}

1) Arscott, G.H. and L.A. SAther Poultry Sci., $37: 844,1958$.

2) Begin, J.J. ibid., 40:892, 1961.

3) Berglund, R. Feedstuffs, 34:43, 6, 1962.

4) Biely, J. and B. March Poultry Sci., 36: 1253, 1957.

5) BIRD, H.R. ibid., 22:205, 1943.

6) and D. Whitson ibid., $25: 210$, 1946.

7) Bolton, W. and V.N. Murty J. Agr. Sci., $55: 203,1960$.
8) Burr, G.O. J. Biol. Chem., $82: 345,1929$.

9) Carver, D.S. and E.L. Johnson Poultry Sci., $32: 701,1953$.

10) — ibid., $38: 71,1959$.

11) Сомвs, G.F. Feedstuffs, 31:12, 34, 1959.

12) - and N.V. Helbacka Poultry Sci., $39: 271,1960$.

13) Couch, J.R. Feedstuffs, 28:47, 46, 1956.

14) Cullen, M.P., O.G. Rasmussen and O.H.M. Wilder Poultry Sci., $41: 360,1962$.

15) Daghir, N.J., W.W. Marion and S.L. Balloun ibid., 39: 1459, 1960.

16) and S.L. Balloun ibid., $40: 1712$, 1961.

17) Dam, R., R.M. Leach JR., T.S. Nelson, L.C. Norris and F.W. HILL J. Nutrition, 68: $615,1959$.

18) DANSKY, L.M. Poultry Sci., 41: 1352, 1962.

19) Doberenz, A.R., D.L. SChNeider, A.A. KuRnick, M.G. Vayich and A.R. Kemmerer Proc. Soc. Exptl. Med., 105 : 359, 1960.

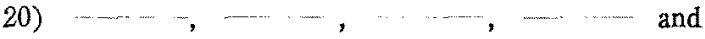
Poultry Sci., 41:700, 1962.

21) Donaldson, W. E., G. F. Combs and G. L. RoMoser ibid., 33:1053, 1954.

22) $\ldots$ and - ibid., 35 :

23) $1100,1956$. $614,1958$.

24) — ibid., $41: 1060,1962$.

25) Douglas, C.R. and R.H. Harms ibid., 39 : $54,1956$.

26) Edwards, JR., H. M., W. S. Dunahoo, J. L. Carmon and H.L. Fuller ibid., $39: 6,1389$, 1960.

27) — - J. E. Marion and J. C. Driggers ibid., $40: 811,1961$.

28) - - and - ibid., $41=$ $713,1962$.

29) Engminger, M.E. Feedstuffs, 28: 13, 49, 1956.

30) Evans, R.J., S.L. Bandemer, J. A. Davidson. and P.J. Schatble ibid., 36:798, 1957.

31) - $\longrightarrow$, $\longrightarrow$ and ibid., $37: 977,1958$.

32) - J.A. Davidson and S.L. Bandemer J. Nutrition, $73: 282,1961$.

33) - S. L. Bandemer, M. Anderson and J.A. DAVIDSON ibid., $76: 314,1962$.

34) Fedde, M.R., P.E. Walbel and R.E. Burger ibid., $70: 447,1960$.

35) Feedstuffs， $34: 35,14,1962$ より引用.

36) Fischer, H. and G.A. Levellie J. Nutrition, $63: 119,1957$.

37) Gerry, R.W. Maine Agri. Expt. Sta. Bull. $523,1954$. 
38) Greene, D.E., H.M. Scott and H.W. Norton Poultry Sci., $39: 7,1960$.

39) Hammond, J.C. and H.M. HaRshaw ibid., 20 : $437,1941$.

40) Heman, V. and L.W. TIGHe ibid., $22: 102$, 1943.

41) Henderson, E.W. and W.E. IrWIN ibid., 19: $389,1940$.

42) Heywang, B.W. World's Poultry Sci. J. 18 : $147,1962$.

43) Hill, F.W., D.L. Anderson and L.M. Dansiky Poultry Sci., 33: 1059, 1954.

44) - - , - and - Proc. Cornell Nurition Conference for Feed Manufacturers, 47, 1954.

45) $\longrightarrow$ and $\longrightarrow$ Poultry Sci., $35: 54,1956$.

46) — Feedstuffs, 28:29, 52, 1956.

47) Hochreich, H.J., C.R. Douglas, I.H. Kidd and R.H. HARMS Poultry Sci., $37: 949,1958$.

48) Hunt, J.R., J.R. Aitken and W.G. Hunsaker ibid., $40: 1193,1961$.

49) Johnson, E.L. and P.E. Waibel Feedstuffs, $28: 27,18,1956$.

50) 勝木辰男・紺野 耕- 大淵 進 日獣章大紀要, $11: 52,1962$.

51) Kummerow, F.A., R. Wever and H. Honstead Poultry Sci., $28: 475,1949$.

52) Leong, K.C., M.L. Sunde, H.R. Bird and K.G. WECKEL ibid., $37: 1170,1958$.

53) — - — - - - and C.A. ELVEHJEM ibid., $38: 1267,1959$.

54) Lewis, R. W., J. J. Woods and J. R. Covch ibid., $39: 910,1960$.

55) Lillie, R.J., J.R. Sizemore, J.L. Milligan and H.R. BIRD ibid., 31: 1037, 1952.

56) - - and C.A. Denton ibid., $36: 755,1957$.

57) MacFarland, J. J., F.S. Shenstone and J.R. VoCkery Nature, 179:830, 1957.

58) Machlin, L.J. and C.W. Pope Poultry Sci., $41: 1340,1962$.

59) - - R.S. Gordon, J.E. MARR and C.W. POPE J. Nutrition, $76: 284,1962$.

60) Macintyre, T.M. and J.R. Aitken Poultty Sci., 36:1211, 1957.

61) MARCh, B.E. and J. Blety ibid., 33:1069, 1954.

62) - and

63) and

64) - and

$-$

ibid., $35: 545,1956$.

65) - - - and ibid., $36: 1270,1957$. ibid, $41: 9,1962$. ibid., $42: 20,1963$.

66) Marion, J.E. and H.M. Edwards, JR. ibid., $41: 1785,1962$.

67) $\longrightarrow$ J. Nutri., $79: 53$,
68) MCDaniel, A.H., J.H. Quisenberry, B.L. Reid and J.R. Couch Poultry Sci., 36:850, 1957.

69) -.... J. H. Quisengerry, B.L. Reid and J.R. Couch ibid., 38:213, 1959.

70) Masson, J.C., M.G. Varich, B.W. Heywang and A.R. Kemmerer Science, $126: 751,1957$.

71) Mehring, A.L., L.N. Loyd, JR., D. TOHNSOn, JR. and H.W. Titus Pouitry Sci., 40:826, 1961.

72) Menge, H. and C.A. Denton J. Nutrition, $75: 107,1961$.

73) Miller, E.C., H. Menge and C. A. Denton ibid., $80: 431,1963$.

74) Mraz, F.R., R.V. Boucher and M.G. McCartney Poultry Sci., $37: 1308,1958$.

75) Murty, N.L. and R. Reiser J. Nutrition, $75: 2287,1961$.

76) Naber, E.C. and C.L. Morgan Poultry Sci., $36: 727,1957$.

77) Ostrander, J.G., R. Jordan, W.J. Stadelman, J.C. Rogler and G.E. VAll ibid., $39: 746$, 1960.

78) Pepper, W.F., S.J. Slinger and E.S. Snyder ibid., $32: 921,1953$.

79) ——, - - and J.D. Summers ibid., $39: 66,1960$.

$80)$ and I.R. SIBBALD ibid., $41: 1163,1962$.

81) Potrer, L. M., L. D. Matterson and E.P. SINGSEN ibid., $39: 1178,1960$.

82) Price, J.D., A.H. McDaniel, D.N. Smith, JR., J.H. Quisenberky, B.L. Reid and J.R. Couch ibid., $36: 1316,1957$.

83) Quillen, E.C., G.F. Combs, R.D. CreEk and G.L. Romoser ibid., $40: 639,1961$.

84) Quisenberry, J.H., R.M. Sherwood and H.L. GERMAN ibid., 28:780, 1949.

85) Rand, N.T., H.M. Scott and F.A. Kummerow ibid., 37: 1075, 1958.

86) Reiser, R. and P.B. Pearson J. Nutrition, $38: 244,1949$.

87) - J. Nutrition, 44: 159, 1951.

88) Renner, R. and F.W. Hill Poultry Sci., $39: 849,1960$.

89) Roeerston, E.I., R.E. Miller and G.F. Heliser ibid., $27: 736,1948$.

90) Runnels, T.D. ibid., 33: 1090, 1954.

91) Schnelder, D.L., A.A. KuRnick, M.G. VAvich and A.R. Kemmerer ibid, 41: 1005, 1962.

92) Sell, J.L. and G.C. Hodgson J. Nutrition, $76: 113,1962$.

93) Shenstone, F.S. and J.R. Vickery Poultry Sci., $38: 1055,1959$.

94) Shutze, J.V., L.S. Jensen and J. McGinnis ibid., $41: 1846,1962$. 
95) Sibbaid, I.B., S.J. Slinger and W.F. Pepper ibid., $41: 1254,1962$.

96) Siedeler, A.L. and B.S. Schweigert ibid., $32: 449,1951$.

97) Singsen, E.P., L.D. Matterson and A. Kozeff Storrs (Connecticut) Agri. Expt. Sta. Bull. 286, 1952.

98) Skinner, J.L., J.H. Quisenberry and J.R. Couch Poultry Sci., $30: 319,1951$.

99) Summers, J.D., S. J. Stinger, I. MotzoK and G.C. Ashton ibid., 39:664, 1960.

100) SUNDE, M.L. ibid., 35:350, 1956.

101) — ibid., $35: 362,1956$.

102) - J. American Oilchem. Soc., 31: 49, 1954.

103) TayloR, M.W., F.P. JefFley and W.C. Russel Poultry Sci. 23 : 155, 1944.

104）田先威和夫・苔荷 澄 日畜会報, 33: 別号 23,
1962.

105) Thomas, C.H., E.W. Glazener and W.L. Blow Poultry Sci., 37: 1177, 1958.

106) Thornton, P.A. and W.A. Whittet ibid., $39: 916,1960$.

107) Treat, C.M., B.L. Beid, R.E. Davies and J.R. Couch ibid., $39: 1550,1960$.

108) TuRK, D.E., H.R. Bird and M.L. SundE ibid., $37: 1249,1958$.

109) TuRPeinen, Q. J. Nutrition, $15: 351,1938$.

110) WeISS, H.S. and H. FisHeR ibid., $61: 267$, 1957.

111) WiLGus, H.S. Feedstuffs, $29: 47,34,1957$.

112) Williams, W.P. ibid., $31: 37,92,1959$.

113) Yacowitz, H. Poultry Sci., 32:930, 1953.

114) and V. D. Chamberin ibid., 33, $1090,1954$. 